IZA DP No. 9685

Employment Adjustments around Childbirth

Barbara Pertold-Gebicka

Filip Pertold

Nabanita Datta Gupta

January 2016 


\title{
Employment Adjustments around Childbirth
}

\author{
Barbara Pertold-Gebicka \\ Charles University in Prague
}

Filip Pertold

CERGE-EI

Nabanita Datta Gupta

Aarhus University and IZA

\author{
Discussion Paper No. 9685 \\ January 2016
}

IZA

P.O. Box 7240

53072 Bonn

Germany

Phone: +49-228-3894-0
Fax: +49-228-3894-180
E-mail: iza@iza.org

Any opinions expressed here are those of the author(s) and not those of IZA. Research published in this series may include views on policy, but the institute itself takes no institutional policy positions. The IZA research network is committed to the IZA Guiding Principles of Research Integrity.

The Institute for the Study of Labor (IZA) in Bonn is a local and virtual international research center and a place of communication between science, politics and business. IZA is an independent nonprofit organization supported by Deutsche Post Foundation. The center is associated with the University of Bonn and offers a stimulating research environment through its international network, workshops and conferences, data service, project support, research visits and doctoral program. IZA engages in (i) original and internationally competitive research in all fields of labor economics, (ii) development of policy concepts, and (iii) dissemination of research results and concepts to the interested public.

IZA Discussion Papers often represent preliminary work and are circulated to encourage discussion. Citation of such a paper should account for its provisional character. A revised version may be available directly from the author. 
IZA Discussion Paper No. 9685

January 2016

\section{ABSTRACT}

\section{Employment Adjustments around Childbirth}

Using rich longitudinal register data from Denmark, we show that the allocation of mothers between the competitive private sector and the family-friendly public sector significantly changes around the birth of their first child. Specifically, mothers - post first childbirth - are increasingly switching from the private to the public sector and are also less likely to leave the public sector. The incidence of switching sectors can be partly explained by occupational characteristics, such as the convexity of pay and time pressure. In line with the compensating wage differential theory, we observe that the switch into the public sector is accompanied with a wage drop.

JEL Classification: J13, J16, J24

Keywords: motherhood, employment, sector switching, occupational characteristics

Corresponding author:

Nabanita Datta Gupta

Department of Economics and Business

Aarhus University

Fuglesangs Allé 4

8210 Aarhus V

Denmark

E-mail: ndg@econ.au.dk

* Barbara Pertold-Gebicka acknowledges support from the Grant Agency of the Czech Republic grant No. 14-26574P. Filip Pertold acknowledges support from The Danish Council for Independent Research | Social Sciences (FSE) Grant \#0602-00880B and from the Neuron Foundation. 


\section{Introduction}

Motherhood alters women's labor market activity. Not only does it imply a break in employment and a related stagnation of human capital, it also changes the time constraint. Recent literature documents several channels through which women react to this event by adjusting their careers. These include reduction in hours worked (Herr 2015) or taking advantage of family-friendly jobs with flexible working schedule or the possibility to work from home (Felfe 2012). ${ }^{1}$ As noted by Goldin (2014), reduction of working hours or a flexible working schedule is heavily punished in terms of wages in some jobs but less in others. In this paper we thus hypothesize that mothers having jobs with unfavorable conditions for combining motherhood and career are motivated to look for new, family-friendly employment.

According to the classical view on job choice, women choose an employment track at the beginning of their career keeping in mind future fertility and related restrictions (Grolich and de Grip 2009). Nevertheless, as documented in Figure 1, the allocation of mothers across employment sectors significantly changes after the birth of their first child, which is indicative evidence for changing jobs in response to maternity. ${ }^{2}$ This can be considered to be in line with theories that view job match quality as an experience good (Light and McGarry 1998). As mothers learn how difficult it is to combine motherhood and career within their current employment, they may look for a new job with more family-friendly attributes.

\footnotetext{
${ }^{1}$ Leaving the labor market, either temporarily or permanently, may be yet another response, as in the so-called "opting out revolution" in North America. Few studies find evidence for this phenomenon. Antecol (2010) finds increasing overall child penalties for white college-educated married women working in male-dominated jobs, though not on the extensive margin. Thus, the focus here is on strategies that combine motherhood and work. ${ }^{2}$ Related to this, data from the U.S. Census Bureau's SIPP (Survey of Income and Program Participation) panels show that among women who worked during pregnancy and returned to work within a year after birth, $18.6 \%$ in 2005-2007 were observed with a different employer, up from 16.7\% in 2000-2004 (Laughlin, 2011).
} 


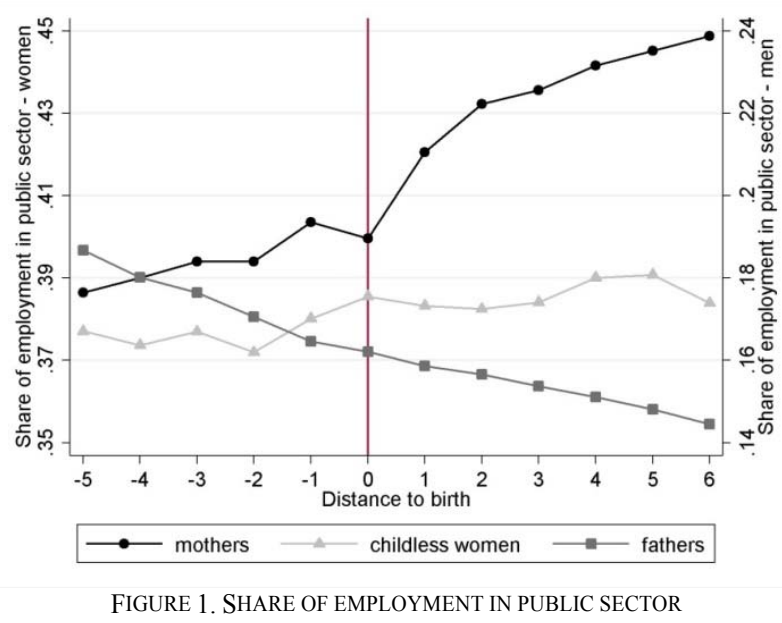

Note: Each point in this graph corresponds to the share of workers within each distance to birth (as measured in years) who are employed in the public sector, which adds up to one with share employed in the private sector. The sample consists of Danish men and women who had their first child in the age-interval 26-33. Childless women are defined as women who do not have any children by the last observation year. For childless women the counterfactual age at first birth was imputed using the distribution of actual age at first birth among mothers with similar characteristics. See the appendix for more detail.

Goldin (2014) compellingly argues that within-occupation inflexibilities with respect to hours spent at work stand behind the penalization of women, however no previous study has attempted to link these job attributes, such as time pressure or convexity of pay with respect to time spent at work, to employment mobility among mothers. In this paper we take advantage of the dual structure of the Danish labor market to shed more light on employment adjustments after childbirth and how these relate to the characteristics of jobs held around the time of a birth. Like in many countries, there are two large employment sectors in Denmark: public and private. The public sector represents family-friendly establishments, while the private sector represents employers with job attributes less suitable for combining motherhood and career. ${ }^{3}$

Using rich longitudinal register data, we provide evidence that a significant share of mothers increasingly adjust sectorial allocation in the time after giving birth to their first child by switching from the private to the public sector. We further show that to a large extent the

\footnotetext{
${ }^{3}$ Family-friendliness of the public sector has previously been recognized, among others, by Albrecht et al. (1999), Datta Gupta and Smith (2000), Nielsen, Simonsen, and Verner. (2004), Datta Gupta, Smith and Verner (2008), and Duvivier and Narcy (2014) who discuss the drivers of the motherhood wage gap in public and private sectors in Sweden, Denmark, and France. They find that public sector employees experience a lower family wage gap than private sector employees and argue that one of the reasons lies in the dependence of wages and career path in the public sector on years of service (maternity leave inclusive) rather than time actually spent at work.
} 
incidence of switching sectors is explained by the characteristics of pre-switch occupations, namely time pressure and convexity of pay schemes with respect to hours worked. In line with the compensating wage differential theory, with find that mothers who leave the private sector and become employed in the public sector experience a drop in hourly wages. We also show that mothers who start their careers in the public sector are less likely to leave the public sector in later stages of their career (compared to fathers or childless women of the same age and education who also start their careers in the public sector).

Overall, our findings suggests that mothers seek specific employers (in our case represented by the public sector), which to some extent helps them overcome barriers to combining motherhood and career. Such sorting-specifically due to the event of motherhood-into a familyfriendly sector and which is directly related to the convexity of pay and lack of flexibility in the private sector has not previously been shown in the literature. ${ }^{4}$

\section{Data and Methods}

For the purpose of this study we use Danish register data. This dataset has a panel structure and contains detailed socio-economic information on all individuals living in Denmark. We base our analysis on a sample of Danish women (and men) born in 1969, 1970, and 1971. The choice of these three birth cohorts is driven by the availability of occupational data limited to 19912008 and the focus of our analysis on women of childbearing age. We concentrate on mothers (and fathers) who had their first child between the ages of 26 and $33 .^{5}$

We observe employment status, type of employer, yearly and hourly earnings, and 2-digit occupations at the end of November of each calendar year. Additionally, we observe birth dates

\footnotetext{
${ }^{4}$ Previous cross-sectional evidence from a single year (1997) from Denmark has shown that being a mother and having a lower expected rate of wage compensation during maternity leave in the private sector significantly increased a woman's probability of being employed in the public sector (Nielsen, Simonsen, and Verner 2004). ${ }^{5}$ This age range covers about 70 percent of all first-time mothers in the analyzed cohorts. We also performed robustness checks with different definition of age range at first birth and results remain unchanged. The results can be provided upon request.
} 
of all children. Occupational characteristics are retrieved from the O*NET database. To match occupations coded by ISCO -the occupational classification used in Europe- with occupational characteristics as provided by the $\mathrm{O}$ *NET database, we apply manual matching facilitated with the crosswalk provided by the US Bureau for Labor Statistics (2012). Whenever applicable, wages are deflated to their 2005 level.

Table 1 provides basic statistics summarizing the data used in this study. We observe in total more than 51,000 fathers, 50,000 mothers and 12,000 childless women ${ }^{6}$ for a period of 19 years. It can be seen from the table that women are much more often employed in the family-friendly public sector than men and that employment in the public sector significantly increases over age for mothers, but does not change much for childless women or fathers. We also observe the already well documented fact that the earnings gap between mothers and fathers widens more in the private sector than in the public sector after the first birth (Albrecht et al. 1999, Datta Gupta and Smith 2000, Nielsen, Simonsen, and Verner. 2004).

These statistics, combined with the stylized facts depicted in Figure 1, are suggestive of the behavior of mothers in the labor market. It appears that a large share of mothers self-select to the public sector at the beginning of their careers, which might be driven by a desire to combine future family life and career. This is in line with earlier studies that model sectorial allocation and fertility decisions simultaneously (Nielsen, Simonsen, and Verner 2004). New evidence presented here suggests a further inflow of mothers into the public sector after having a first child. In particular, the share of mothers in the public sector increases by 17 percent ( 7 percentage points). This suggests that some women who started their careers in the private sector might reallocate to the public sector in response to having children.

\footnotetext{
${ }^{6}$ Childless women are defined as women who do not have children by the last observation year, i.e. 2008 . In this year they are 37-39 years old.
} 


\begin{tabular}{|c|c|c|c|c|c|c|}
\hline & \multicolumn{2}{|c|}{ Mothers } & \multicolumn{2}{|c|}{ Childless Women } & \multicolumn{2}{|c|}{ Fathers } \\
\hline & At age 25 & At age 35 & At age 25 & At age 35 & At age 25 & At age 35 \\
\hline Log earnings in the public sector & 11.34 & 12.15 & 11.18 & 12.12 & 11.42 & 12.40 \\
\hline Log earnings in the private sector & 11.67 & 12.21 & 11.57 & 12.26 & 11.97 & 12.54 \\
\hline \multicolumn{7}{|l|}{ Share of employment in the public sector: } \\
\hline All & 0.40 & 0.47 & 0.37 & 0.40 & 0.17 & 0.16 \\
\hline Employed in public s. at age 25 & - & 0.76 & - & 0.70 & - & 0.50 \\
\hline Employed in private s. at age 25 & - & 0.23 & - & 0.21 & - & 0.07 \\
\hline Share of employment in high-skilled occupations & 0.04 & 0.18 & 0.04 & 0.19 & 0.05 & 0.21 \\
\hline Age when having the first child & \multicolumn{2}{|c|}{27.4} & \multicolumn{2}{|c|}{-} & \multicolumn{2}{|c|}{29.3} \\
\hline Observations & \multicolumn{2}{|c|}{50,459} & \multicolumn{2}{|c|}{12,036} & \multicolumn{2}{|c|}{51,253} \\
\hline
\end{tabular}

To further analyze this latter phenomenon, we estimate the year-to-year propensity of switching from private to public sector (and, for completeness, from public to private sector) by regressing the switching indicator on a set of dummies corresponding to distances to and from birth and other explanatory variables. As the distance to birth effect might confound with the age effect, we add a reference group. In our preferred specification fathers are used as such a group, because they allow for exact definition of the post-birth period and have been used in recent studies (Angelov, Johansson, and Lindahl forthcoming, Kleven, Landais, and Sogaard 2015). ${ }^{7}$ To highlight the role of job characteristics in switching patterns, we add control variables corresponding to different measures of family-friendliness of the occupation where an individual was employed in the last period. These measures are either derived from the O*NET database, or estimated using the Danish register data. Specifically, we estimate the convexity of monthly pay (i.e. salary) with respect to hours worked for each 2-digit occupation using Mincer-type regressions with log-salary as the dependent variable and log-hours as one of the explanatory variables. ${ }^{8}$ Following Goldin (2014) we extract from O*NET four occupational characteristics that seem to be the most relevant for our analysis. These are "freedom to make decisions", "contact with others", "structured vs. unstructured work", and "time pressure", all listed in the Work Context category.

\footnotetext{
${ }^{7}$ Results using childless women as the reference group are presented in the appendix and they provide qualitatively similar findings.

${ }^{8}$ The convexity of pay was alternatively estimated using the Danish Work Environment Cohort Study 2000 database, where the hours measure is self-reported as opposed to the contracted hours as available in the register data. Wage-hours elasticities based on these two datasets are similar (results available on request).
} 
In the next step we consider the possible effects of the observed relocation between less and more family-friendly employers on mothers' labor market outcomes. We regress yearly changes in wages, hours worked, and the probability of being employed in a high skilled position on the indicator of sectorial switch and the interaction of sectorial switch with the motherhood status.

\section{Results}

We visualize the regression results for year-to-year switching propensity by plotting the coefficients corresponding to the estimates of the family gap (mothers minus fathers) in the probability of switching from private to public sector (Figure 2, Panel A) and from public to private sector (Figure 2, Panel B) at each distance to birth. Each line corresponds to a different set of control variables. It can be seen that the family gap in switching from the less familyfriendly sector to the more family-friendly sector increases significantly after the birth of the first child and grows with each year. This evidence suggests that mothers may learn over time how difficult it is to combine motherhood with career and the likelihood of switching sectors therefore increases over time (compared to fathers). Patterns concerning switching from the more family-friendly sector to the less family-friendly sector are different. We observe fathers being more likely to switch from the public to the private sector than mothers, with the family gap being largest two years after birth. 
Panel A: From private to public

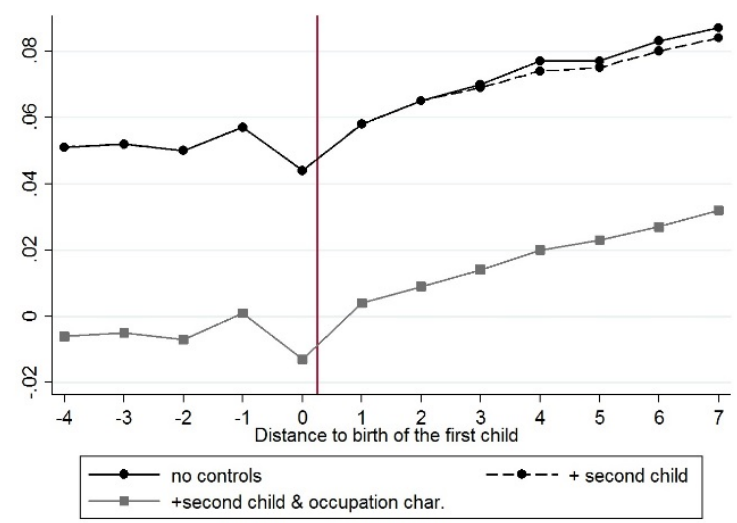

Panel B: From public to private

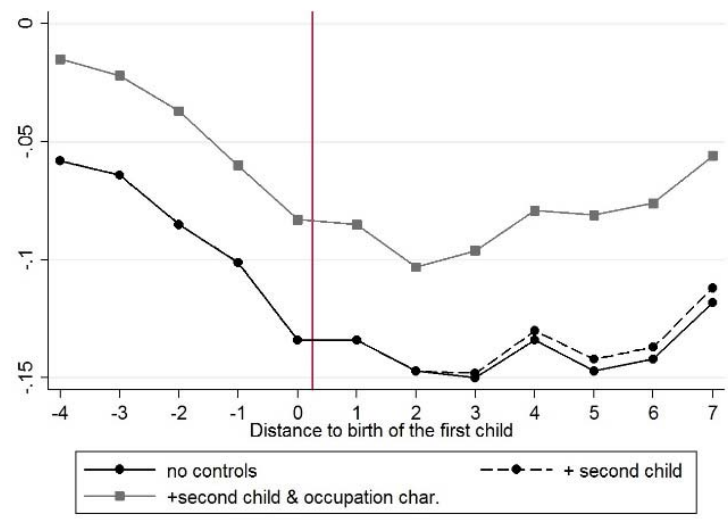

FIGURE 2. FAMILY GAP IN THE PROBABILITY OF SWITCHING

Note: Each dot represents a point estimate of the coefficient corresponding to the motherhood effect (mothers vs. fathers) at each distance to birth. Full regression tables can be found in the appendix.

Adding measures of family-friendliness of the previous year's occupation as control variables explains large part of the difference in the probability to switch between mothers and fathers. The estimated parameters corresponding to the interactions of the mother dummy with occupation characteristics suggest that mothers are more likely to switch away from occupations with high elasticity of pay, high freedom to make decisions, and involving intensive contact with others. ${ }^{9}$

We further analyze what happens to labor market outcomes, in particular hourly wages, annual hours worked, and skill level of occupation, for mothers who switch sectors. Table 2 reports the estimated effects of switching sectors on outcomes of mothers who were employed in the private (public) sector in the previous year. We observe that relocating from the private to the public sector is generally associated with a drop in wages. Nevertheless, we find that when the switch from the private into the public sector occurs after giving birth to the first child, the drop in wages and hours worked is significantly smaller and likelihood to be promoted into high skilled occupations is higher. We further find that the switch from the public into the private

\footnotetext{
${ }^{9}$ Detailed results are presented in the appendix table $1 \mathrm{~A}$.
} 
sector (Panel B) is associated with an economically small increase in wages, which disappears when the switch occurs after birth.

Such findings are consistent with the previously documented fact that the private sector limits career progress and wage growth of mothers post first childbirth more than the public sector. Potential wage loss occurring as a consequence of switching from the private into the public sector (and the gain from switching from the public into the private sector) may therefore decrease in the post-birth period.

TABLE 2- EFFECTS OF YEAR TO YEAR CHANGES IN SECTORIAL ALLOCATION ON WAGES, HOURS AND OCCUPATION SKILL LEVEL

\begin{tabular}{|c|c|c|c|}
\hline & $\Delta$ Log hourly wage & $\Delta$ Hours worked & $\Delta$ Probability of high-skilled occupation \\
\hline \multicolumn{4}{|l|}{ Panel A. Employed in the private sector in $t-1$} \\
\hline Sector switch & $\begin{array}{c}-0.116^{* * * *} \\
(0.005)\end{array}$ & $\begin{array}{c}-236.298 * * * \\
(7.272)\end{array}$ & $\begin{array}{c}-0.006 * * * \\
(0.003)\end{array}$ \\
\hline After birth & $\begin{array}{c}-0.041 * * * \\
(0.005)\end{array}$ & $\begin{array}{c}-125.487 * * * \\
(4.739)\end{array}$ & $\begin{array}{c}-0.011 * * * \\
(0.002)\end{array}$ \\
\hline After birth*sector switch & $\begin{array}{c}0.078 * * * \\
(0.008)\end{array}$ & $\begin{array}{c}170.978 * * * \\
(10.771)\end{array}$ & $\begin{array}{c}0.065 * * * \\
(0.005)\end{array}$ \\
\hline Constant & $\begin{array}{c}-0.935 * * * \\
(0.014)\end{array}$ & $\begin{array}{c}-486.186^{* * *} \\
(18.975)\end{array}$ & $\begin{array}{c}-0.236 * * * \\
(0.009)\end{array}$ \\
\hline Obs. & 145640 & 145640 & 145640 \\
\hline R-squared & 0.054 & 0.024 & 0.018 \\
\hline \multicolumn{4}{|l|}{ Panel B. Employed in the public sector in $t-1$} \\
\hline Sector switch & $\begin{array}{c}0.013 * * \\
(0.006)\end{array}$ & $\begin{array}{c}-78.639 * * * \\
(7.134)\end{array}$ & $\begin{array}{c}-0.051 * * \\
(0.004)\end{array}$ \\
\hline After birth & $\begin{array}{l}-0.005 \\
(0.007)\end{array}$ & $\begin{array}{c}-81.648 * * * \\
(7.961)\end{array}$ & $\begin{array}{c}-0.019 * * * \\
(0.004\end{array}$ \\
\hline After birth*sector switch & $\begin{array}{c}-0.017 * * \\
(0.009)\end{array}$ & $\begin{array}{l}-37.877 \\
(10.396)\end{array}$ & $\begin{array}{c}0.016^{* * *} \\
(0.005)\end{array}$ \\
\hline Constant & $\begin{array}{c}-1.110^{* * * *} \\
(0.024)\end{array}$ & $\begin{array}{c}-1300 * * * \\
(29.000)\end{array}$ & $\begin{array}{c}-0.536^{* * * *} \\
(0.015)\end{array}$ \\
\hline Obs. & 76013 & 76013 & 76013 \\
\hline R-squared & 0.069 & 0.053 & 0.056 \\
\hline
\end{tabular}

Notes: Table presents OLS regression results for the sample of mothers. The dependent variable is change in log hourly wages, annual hours worked, or the propensity of being employed in a high-skilled occupation between two consecutive years. Control variables include educational level, age, years of experience in the private (Panel A) or public (Panel B) sector, and presence of the second child. High-skilled occupations are defined as "Top executives" and "Employees at the highest level" using the variable pstill defining the primary working position.

*** Significant at the 1 percent level.

** Significant at the 5 percent level.

* Significant at the 10 percent level.

\section{Conclusion}

The evidence presented in this paper illustrates the relationship between fertility and employment reallocation in a labor market consisting of two sectors that differ in the degree to which they enable combining work and family. We show that mothers after giving birth to their first child are more likely to leave the private sector and become employed in the public sector, 
which is generally considered to be the more family-friendly employer. In line with Goldin's (2014) arguments that certain occupations in the private sector heavily punish combining motherhood and career, we show that mothers who switch to the public sector are generally more likely to leave occupations with convex pay schemes and with inflexible working hours. Based on the evidence uncovered in this study, we conclude that the situation of women in the labor market may be impacted not only by affecting their decisions upon entering the labor market (for example through polices targeting their field of study or first occupation), but also by increasing their motivation to stay in the job they hold around the birth of the first child. Public policies should reflect the fact that a large portion of the switching behavior can be explained by the characteristics of occupations (convexity of pay or inflexible working hours), in which mothers are employed before the switch takes place. This implies that offering job schedules which are less dependent on continuous working hours and with greater time flexibility could increase the proportion of women working in the private sector during motherhood. Although our evidence aligns with Goldin's (2014) arguments about the last steps in gender convergence, we leave for future research the question of whether the endogenous sorting of mothers after childbirth, as documented in this paper, has an impact on the wage convergence of males and females in the labor market.

\section{REFERENCES}

Albrecht, James W., Per-Anders Edin, Marianne Sundström and Susan B. Vromann. 1999. Career Interruptions and Subsequent Earnings, Journal of Human Resources. 34, 294-311. Angelov, N., P. Johansson, and E. Lindahl (forthcoming). Parenthood and the Gender Gap in Pay, Journal of Labour Economics, forthcoming 2016.

Bureau of Labor Statistics. 2012. Crosswalk between the International Standard Classification of Occupations (ISCO-08) and the 2010 Standard Occupational Classification (SOC), 
Datta Gupta, Nabanita and Nina Smith. 2000. "Children and Career Interruptions" Working Paper no. 00-03, Center for Labour Market and Social Research, Aarhus.

Datta Gupta, Nabanita, Nina Smith and Mette Verner. 2008."PERSPECTIVE ARTICLE: The impact of Nordic countries' family friendly policies on employment, wages and children" Review of Economics of the Household. 6 (1): 65-89.

Duvivier, Chloé, and Mathieu Nancy. 2014. "The Motherhood Wage Penalty and its Determinants: a Public-Private Comparison" Centre d'études de l'emploi Working Paper No. 172

Felfe, Christina. 2012. "The motherhood wage gap: What about job amenities?" Labour Economics. 19 (1): 59-67.

Fernandez-Kranz, Daniel, Aitor Lacuesta, and Núria Rodriguez-Planas. 2013 “The Motherhood Earnings Dip: Evidence from Administrative Records”. Journal of Human Resources. 48 (1): 169-197.

Goldin, Claudia. 2014. "Grand Gender Convergence: Its Last Chapter”. American Economic Review. 104 (4): 1091-1119.

Grolich, Dennis and Andries de Grip. 2009. "Human Capital Depreciation during Motherhood" Oxford Economic Papers, vol 61: p. 98-121

Herr, Jane L. 2015. "The Labor Supply Effects of Delayed First Birth”. American Economic Review: Papers \& Proceedings. 105 (5): 630-637.

Kleven, Henrik J., Camille Landais and Jakob Egholt Sogaard 2015. "Children and Gender Inequality: Evidence from Denmark" mimeo.

Laughlin, Lynda. 2011. "Maternity Leave and Employment Patterns: 2006-2008”. Current Population Report, P70-128. U.S. Census Bureau, Washington, DC.

Light, Audrey and Kathleen McGarry. 1998 "Job Change Patterns and the Wages of Young Men" The Review of Economic and Statistics. Vol. 80, No 2, pp. 276-286

Nielsen, Helena S., Marianne Simonsen, and Mette Verner. 2004. "Does the Gap in Familyfriendly Policies Drive the Family Gap?” Scandinavian Journal of Economics, 106 (4): 721744. 


\section{Appendix}

\section{A1. Data description}

For the purpose of this study we use Danish register data. This dataset has a panel structure and contains detailed socio-economic information on all individuals living in Denmark. We base our analysis on a sample of Danish women (and men) born in 1969, 1970, and 1971. The choice of these three birth cohorts is driven by the availability of occupational data limited to 1991-2008 and the focus of our analysis on women of childbearing age. Given that the focus of our study is on the comparison of preand post-birth employment choices, we decided to concentrate on mothers (and fathers) who had their first child between the age of 26 and 33 - the interval covering nearly $70 \%$ of all mothers born in years 1969-1971. Widening the age at first birth interval does not change our conclusions, but significantly increases the share of women who have none or very limited work experience prior to giving birth to their first child.

We observe employment status, type of employer, yearly and hourly earnings, and 2-digit occupations (as coded by the Danish occupational system, DISCO, which exactly matches the International Standard Classification of Occupations, ISCO) at the end of November of each calendar year. Whenever applicable, wages are deflated to their 2005 level. Additionally, we observe birth dates of all children. Occupational characteristics are retrieved from the $\mathrm{O}$ NET database. To match occupations coded by DISCO with occupational characteristics as provided by the O*NET database, we apply manual matching facilitated with the crosswalk between the SOC - occupational classification used by the US Bureau for Labor Statistics - and ISCO - the occupational classification used in Europe (Bureau of Labor Statistics, 2012). The occupational classification used in the O*NET database is, however, more detailed than SOC. Thus, in the first step we aggregate the occupational characteristics as provided by O*NET to the 6-digit SOC by using simple averages. Next, we match ISCO occupations with their SOC counterparts using the crosswalk provided by the Bureau for Labor Statistics and aggregate the occupations to the 2-digit ISCO level. In the last step we obtain occupational characteristics at the aggregate level by weighting the O*NET data by employment share of each detailed occupation in the aggregate category. 
In our sample mothers are defined as women who had their first child between the age of 26 and 33 . We observe mothers both before and after they give birth. Fathers are defined accordingly. Mothers and fathers who are observed to have their first child outside of the 26-33 age interval are not included in the sample. Childless women are those for whom we do not observe any birth by the last year of observation, i.e. by 2008. This corresponds to age 37-39. While this definition does not rule out the possibility that childless women eventually become mothers, we do not observe these women while having children. We assign an artificial birth year to each childless woman based on the observed distribution of the age at first birth among mothers with the same observable characteristics, namely education level and the age at which their mothers had the first child. This is used for computation of statistics presented in Figure 1 and estimations visualized in Figure 2A. 
A2. Tables

TABLE 1A-FAMILY GAP IN THE PROBABILITY OF SWITCHING FROM PRIVATE TO PUBLIC SECTOR - MOTHERS VS. FATHERS

\begin{tabular}{|c|c|c|c|c|c|c|c|c|c|}
\hline & $\begin{array}{c}\text { (1) } \\
\text { No controls }\end{array}$ & $\begin{array}{c}\text { (2) } \\
+\begin{array}{c}\text { Second } \\
\text { child }\end{array}\end{array}$ & $\begin{array}{c}\text { (3) } \\
+ \text { Convexity }\end{array}$ & $\begin{array}{c}\text { (4) } \\
+ \text { Time } \\
\text { pressure }\end{array}$ & $\begin{array}{c}\text { (5) } \\
+ \text { Contact } \\
\text { with others }\end{array}$ & $\begin{array}{c}(6) \\
+ \text { Freedom to } \\
\text { make } \\
\text { decisions } \\
\end{array}$ & $\begin{array}{c}\text { (7) } \\
\text { All controls }\end{array}$ & $\begin{array}{c}(8) \\
+ \text { College }\end{array}$ & $\begin{array}{c}\text { (9) } \\
\text { Occupation } \\
\text { dummies }\end{array}$ \\
\hline Sector tenure & $\begin{array}{c}-0.006^{* * *} \\
(0.000)\end{array}$ & $\begin{array}{c}-0.006 * * * \\
(0.000)\end{array}$ & $\begin{array}{c}-0.007^{* * *} \\
(0.000)\end{array}$ & $\begin{array}{c}-0.009 * * * \\
(0.000)\end{array}$ & $\begin{array}{c}-0.009 * * * \\
(0.000)\end{array}$ & $\begin{array}{c}-0.009 * * * \\
(0.000)\end{array}$ & $\begin{array}{c}-0.008^{* * *} \\
(0.000)\end{array}$ & $\begin{array}{c}-0.008^{* * *} \\
(0.000)\end{array}$ & $\begin{array}{c}-0.004^{* * *} \\
(0.000)\end{array}$ \\
\hline 4 years before birth $*$ mother & $\begin{array}{c}0.051^{* * *} \\
(0.002)\end{array}$ & $\begin{array}{c}0.051^{* * *} \\
(0.002)\end{array}$ & $\begin{array}{c}-0.012^{* * *} \\
(0.004)\end{array}$ & $\begin{array}{c}0.013^{* * *} \\
(0.004)\end{array}$ & $\begin{array}{l}-0.006 \\
(0.004)\end{array}$ & $\begin{array}{c}0.010 * * * \\
(0.003)\end{array}$ & $\begin{array}{l}-0.006 \\
(0.004)\end{array}$ & $\begin{array}{l}-0.005 \\
(0.004)\end{array}$ & $\begin{array}{c}0.032 * * * \\
(0.003)\end{array}$ \\
\hline 3 years before birth $*$ mother & $\begin{array}{c}0.052 * * * \\
(0.002)\end{array}$ & $\begin{array}{c}0.052 * * * \\
(0.002)\end{array}$ & $\begin{array}{c}-0.011^{* * *} \\
(0.004)\end{array}$ & $\begin{array}{c}0.015^{* * *} \\
(0.004)\end{array}$ & $\begin{array}{l}-0.004 \\
(0.004)\end{array}$ & $\begin{array}{c}0.013^{* * *} \\
(0.003)\end{array}$ & $\begin{array}{l}-0.005 \\
(0.004)\end{array}$ & $\begin{array}{l}-0.004 \\
(0.004)\end{array}$ & $\begin{array}{c}0.023^{* * *} \\
(0.002)\end{array}$ \\
\hline 2 years before birth $*$ mother & $\begin{array}{c}0.050 * * * \\
(0.002)\end{array}$ & $\begin{array}{c}0.050 * * * \\
(0.002)\end{array}$ & $\begin{array}{c}-0.013 * * * \\
(0.004)\end{array}$ & $\begin{array}{c}0.012 * * * \\
(0.004)\end{array}$ & $\begin{array}{l}-0.007^{*} \\
(0.004)\end{array}$ & $\begin{array}{c}0.009 * * * \\
(0.003)\end{array}$ & $\begin{array}{l}-0.007^{*} \\
(0.004)\end{array}$ & $\begin{array}{l}-0.007^{*} \\
(0.004)\end{array}$ & $\begin{array}{c}0.020 * * * \\
(0.002)\end{array}$ \\
\hline 1 year before birth $*$ mother & $\begin{array}{c}0.057^{* * *} \\
(0.002)\end{array}$ & $\begin{array}{c}0.057^{* * *} \\
(0.002)\end{array}$ & $\begin{array}{l}-0.006 \\
(0.004)\end{array}$ & $\begin{array}{c}0.019 * * * \\
(0.004)\end{array}$ & $\begin{array}{c}0.000 \\
(0.004)\end{array}$ & $\begin{array}{c}0.017^{* * *} \\
(0.003)\end{array}$ & $\begin{array}{c}0.001 \\
(0.004)\end{array}$ & $\begin{array}{l}-0.000 \\
(0.004)\end{array}$ & $\begin{array}{c}0.024 * * * \\
(0.002)\end{array}$ \\
\hline birth year * mother & $\begin{array}{c}0.044^{* * *} \\
(0.002)\end{array}$ & $\begin{array}{c}0.044 * * * \\
(0.002)\end{array}$ & $\begin{array}{c}-0.019 * * * \\
(0.004)\end{array}$ & $\begin{array}{c}0.005 \\
(0.004)\end{array}$ & $\begin{array}{c}-0.014 * * * \\
(0.004)\end{array}$ & $\begin{array}{c}0.002 \\
(0.003)\end{array}$ & $\begin{array}{c}-0.013^{* * *} \\
(0.004)\end{array}$ & $\begin{array}{c}-0.014 * * * \\
(0.004)\end{array}$ & $\begin{array}{c}0.014 * * * \\
(0.002)\end{array}$ \\
\hline 1 year after birth $*$ mother & $\begin{array}{c}0.058^{* * *} \\
(0.002)\end{array}$ & $\begin{array}{c}0.058^{* * *} \\
(0.002)\end{array}$ & $\begin{array}{l}-0.004 \\
(0.004)\end{array}$ & $\begin{array}{c}0.021^{* * *} \\
(0.004)\end{array}$ & $\begin{array}{c}0.002 \\
(0.004)\end{array}$ & $\begin{array}{c}0.018^{* * *} \\
(0.003)\end{array}$ & $\begin{array}{c}0.004 \\
(0.004)\end{array}$ & $\begin{array}{c}0.003 \\
(0.004)\end{array}$ & $\begin{array}{c}0.025^{* * *} \\
(0.002)\end{array}$ \\
\hline 2 years after birth $*$ mother & $\begin{array}{c}0.065^{* * *} \\
(0.002)\end{array}$ & $\begin{array}{c}0.065^{* * *} \\
(0.002)\end{array}$ & $\begin{array}{c}0.003 \\
(0.004)\end{array}$ & $\begin{array}{c}0.027^{* * *} \\
(0.004)\end{array}$ & $\begin{array}{c}0.008^{* *} \\
(0.004)\end{array}$ & $\begin{array}{c}0.024 * * * \\
(0.003)\end{array}$ & $\begin{array}{c}0.009 * * \\
(0.004)\end{array}$ & $\begin{array}{c}0.008^{* *} \\
(0.004)\end{array}$ & $\begin{array}{c}0.031 * * * \\
(0.002)\end{array}$ \\
\hline 3 years after birth $*$ mother & $\begin{array}{c}0.070 * * * \\
(0.002)\end{array}$ & $\begin{array}{c}0.069 * * * \\
(0.002)\end{array}$ & $\begin{array}{l}0.007^{*} \\
(0.004)\end{array}$ & $\begin{array}{c}0.032 * * * \\
(0.004)\end{array}$ & $\begin{array}{c}0.014^{* * *} \\
(0.004)\end{array}$ & $\begin{array}{c}0.029 * * * \\
(0.003)\end{array}$ & $\begin{array}{c}0.014 * * * \\
(0.004)\end{array}$ & $\begin{array}{c}0.013^{* * *} \\
(0.004)\end{array}$ & $\begin{array}{c}0.036 * * * \\
(0.003)\end{array}$ \\
\hline 4 years after birth $*$ mother & $\begin{array}{c}0.077^{* * *} \\
(0.002)\end{array}$ & $\begin{array}{c}0.074 * * * \\
(0.003)\end{array}$ & $\begin{array}{c}0.015^{* * *} \\
(0.004)\end{array}$ & $\begin{array}{c}0.038 * * * \\
(0.004)\end{array}$ & $\begin{array}{c}0.020 * * * \\
(0.004)\end{array}$ & $\begin{array}{c}0.035^{* * *} \\
(0.004)\end{array}$ & $\begin{array}{c}0.020 * * * \\
(0.004)\end{array}$ & $\begin{array}{c}0.019 * * * \\
(0.004)\end{array}$ & $\begin{array}{c}0.043^{* * *} \\
(0.003)\end{array}$ \\
\hline 5 years after birth $*$ mother & $\begin{array}{c}0.077^{* * *} \\
(0.002)\end{array}$ & $\begin{array}{c}0.075^{* * *} \\
(0.003)\end{array}$ & $\begin{array}{c}0.016^{* * *} \\
(0.004)\end{array}$ & $\begin{array}{c}0.040 * * * \\
(0.004)\end{array}$ & $\begin{array}{c}0.023 * * * \\
(0.004)\end{array}$ & $\begin{array}{c}0.038^{* * *} \\
(0.004)\end{array}$ & $\begin{array}{c}0.023^{* * *} \\
(0.004)\end{array}$ & $\begin{array}{c}0.023^{* * *} \\
(0.004)\end{array}$ & $\begin{array}{c}0.045^{* * *} \\
(0.003)\end{array}$ \\
\hline 6 years after birth $*$ mother & $\begin{array}{c}0.083 * * * \\
(0.003)\end{array}$ & $\begin{array}{c}0.080 * * * \\
(0.003)\end{array}$ & $\begin{array}{c}0.021 * * * \\
(0.004)\end{array}$ & $\begin{array}{c}0.044^{* * *} \\
(0.005)\end{array}$ & $\begin{array}{c}0.027 * * * \\
(0.005)\end{array}$ & $\begin{array}{c}0.042^{* * *} \\
(0.004)\end{array}$ & $\begin{array}{c}0.027^{* * *} \\
(0.005)\end{array}$ & $\begin{array}{c}0.027^{* * *} \\
(0.005)\end{array}$ & $\begin{array}{c}0.048^{* * *} \\
(0.003)\end{array}$ \\
\hline 7 years after birth $*$ mother & $\begin{array}{c}0.087^{* * *} \\
(0.003)\end{array}$ & $\begin{array}{c}0.084 * * * \\
(0.003)\end{array}$ & $\begin{array}{c}0.025^{* * *} \\
(0.004)\end{array}$ & $\begin{array}{c}0.048^{* * *} \\
(0.005)\end{array}$ & $\begin{array}{c}0.031 * * * \\
(0.005)\end{array}$ & $\begin{array}{c}0.046^{* * *} \\
(0.004)\end{array}$ & $\begin{array}{c}0.032^{* * *} \\
(0.005)\end{array}$ & $\begin{array}{c}0.032 * * * \\
(0.005)\end{array}$ & $\begin{array}{c}0.056^{* * *} \\
(0.004)\end{array}$ \\
\hline
\end{tabular}




\begin{tabular}{|c|c|c|c|c|c|c|c|c|c|}
\hline & (1) & $(2)$ & (3) & (4) & (5) & (6) & (7) & (8) & (9) \\
\hline & No controls & $\begin{array}{l}+ \text { Second } \\
\text { child }\end{array}$ & + Convexity & $\begin{array}{l}+ \text { Time } \\
\text { pressure }\end{array}$ & $\begin{array}{l}+ \text { Contact } \\
\text { with others }\end{array}$ & $\begin{array}{l}+ \text { Freedom to } \\
\text { make } \\
\text { decisions }\end{array}$ & All controls & + College & $\begin{array}{c}\text { Occupation } \\
\text { dummies }\end{array}$ \\
\hline 4 years before birth & $\begin{array}{c}-0.031 * * * \\
(0.002)\end{array}$ & $\begin{array}{c}-0.031 * * * \\
(0.002)\end{array}$ & $\begin{array}{c}-0.007 * * * \\
(0.002)\end{array}$ & $\begin{array}{c}-0.017^{* * *} \\
(0.002)\end{array}$ & $\begin{array}{c}-0.009 * * * \\
(0.002)\end{array}$ & $\begin{array}{c}-0.016^{* * *} \\
(0.002)\end{array}$ & $\begin{array}{c}-0.009 * * * \\
(0.002)\end{array}$ & $\begin{array}{c}-0.011 * * * \\
(0.002)\end{array}$ & $\begin{array}{c}-0.019 * * * \\
(0.002)\end{array}$ \\
\hline 3 years before birth & $\begin{array}{c}-0.041^{* * *} \\
(0.002)\end{array}$ & $\begin{array}{c}-0.041 * * * \\
(0.002)\end{array}$ & $\begin{array}{c}-0.019 * * * \\
(0.002)\end{array}$ & $\begin{array}{c}-0.029 * * * \\
(0.002)\end{array}$ & $\begin{array}{c}-0.021^{* * *} \\
(0.002)\end{array}$ & $\begin{array}{c}-0.028^{* * *} \\
(0.002)\end{array}$ & $\begin{array}{c}-0.022 * * * \\
(0.002)\end{array}$ & $\begin{array}{c}-0.025 * * * \\
(0.002)\end{array}$ & $\begin{array}{c}-0.024 * * * \\
(0.002)\end{array}$ \\
\hline 2 years before birth & $\begin{array}{c}-0.048^{* * *} \\
(0.002)\end{array}$ & $\begin{array}{c}-0.048^{* * *} \\
(0.002)\end{array}$ & $\begin{array}{c}-0.027^{* * *} \\
(0.002)\end{array}$ & $\begin{array}{c}-0.036^{* * *} \\
(0.002)\end{array}$ & $\begin{array}{c}-0.029 * * * \\
(0.002)\end{array}$ & $\begin{array}{c}-0.035 * * * \\
(0.002)\end{array}$ & $\begin{array}{c}-0.029 * * * \\
(0.002)\end{array}$ & $\begin{array}{c}-0.034^{* * *} \\
(0.002)\end{array}$ & $\begin{array}{c}-0.029 * * * \\
(0.002)\end{array}$ \\
\hline 1 year before birth & $\begin{array}{c}-0.055^{* * *} \\
(0.002)\end{array}$ & $\begin{array}{c}-0.055^{* * *} \\
(0.002)\end{array}$ & $\begin{array}{c}-0.034^{* * *} \\
(0.002)\end{array}$ & $\begin{array}{c}-0.043^{* * *} \\
(0.002)\end{array}$ & $\begin{array}{c}-0.036^{* * *} \\
(0.002)\end{array}$ & $\begin{array}{c}-0.042^{* * *} \\
(0.002)\end{array}$ & $\begin{array}{c}-0.036^{* * *} \\
(0.002)\end{array}$ & $\begin{array}{c}-0.042 * * * \\
(0.002)\end{array}$ & $\begin{array}{c}-0.033^{* * *} \\
(0.002)\end{array}$ \\
\hline birth year & $\begin{array}{c}-0.057^{* * *} \\
(0.002)\end{array}$ & $\begin{array}{c}-0.057^{* * *} \\
(0.002)\end{array}$ & $\begin{array}{c}-0.036^{* * *} \\
(0.002)\end{array}$ & $\begin{array}{c}-0.046^{* * *} \\
(0.002)\end{array}$ & $\begin{array}{c}-0.038^{* * *} \\
(0.002)\end{array}$ & $\begin{array}{c}-0.045^{* * *} \\
(0.002)\end{array}$ & $\begin{array}{c}-0.039 * * * \\
(0.002)\end{array}$ & $\begin{array}{c}-0.046 * * * \\
(0.002)\end{array}$ & $\begin{array}{c}-0.034 * * * \\
(0.002)\end{array}$ \\
\hline 1 year after birth & $\begin{array}{c}-0.058^{* * *} \\
(0.002)\end{array}$ & $\begin{array}{c}-0.058 * * * \\
(0.002)\end{array}$ & $\begin{array}{c}-0.038^{* * *} \\
(0.002)\end{array}$ & $\begin{array}{c}-0.048^{* * *} \\
(0.002)\end{array}$ & $\begin{array}{c}-0.040 * * * \\
(0.002)\end{array}$ & $\begin{array}{c}-0.047^{* * *} \\
(0.002)\end{array}$ & $\begin{array}{c}-0.041 * * * \\
(0.002)\end{array}$ & $\begin{array}{c}-0.049 * * * \\
(0.002)\end{array}$ & $\begin{array}{c}-0.034 * * * \\
(0.002)\end{array}$ \\
\hline 2 years after birth & $\begin{array}{c}-0.061 * * * \\
(0.002)\end{array}$ & $\begin{array}{c}-0.061 * * * \\
(0.002)\end{array}$ & $\begin{array}{c}-0.040 * * * \\
(0.002)\end{array}$ & $\begin{array}{c}-0.050 * * * \\
(0.002)\end{array}$ & $\begin{array}{c}-0.042 * * * \\
(0.002)\end{array}$ & $\begin{array}{c}-0.049 * * * \\
(0.002)\end{array}$ & $\begin{array}{c}-0.043^{* * *} \\
(0.002)\end{array}$ & $\begin{array}{c}-0.050 * * * \\
(0.002)\end{array}$ & $\begin{array}{c}-0.033^{* * *} \\
(0.002)\end{array}$ \\
\hline 3 years after birth & $\begin{array}{c}-0.060^{* * *} \\
(0.002)\end{array}$ & $\begin{array}{c}-0.060 * * * \\
(0.002)\end{array}$ & $\begin{array}{c}-0.039 * * * \\
(0.002)\end{array}$ & $\begin{array}{c}-0.049 * * * \\
(0.002)\end{array}$ & $\begin{array}{c}-0.041^{* * *} \\
(0.002)\end{array}$ & $\begin{array}{c}-0.047^{* * *} \\
(0.002)\end{array}$ & $\begin{array}{c}-0.042^{* * *} \\
(0.002)\end{array}$ & $\begin{array}{c}-0.048^{* * *} \\
(0.002)\end{array}$ & $\begin{array}{c}-0.032 * * * \\
(0.002)\end{array}$ \\
\hline 4 years after birth & $\begin{array}{c}-0.060^{* * *} \\
(0.002)\end{array}$ & $\begin{array}{c}-0.060 * * * \\
(0.002)\end{array}$ & $\begin{array}{c}-0.040^{* * *} \\
(0.002)\end{array}$ & $\begin{array}{c}-0.048^{* * *} \\
(0.003)\end{array}$ & $\begin{array}{c}-0.041^{* * *} \\
(0.003)\end{array}$ & $\begin{array}{c}-0.047^{* * *} \\
(0.003)\end{array}$ & $\begin{array}{c}-0.041 * * * \\
(0.003)\end{array}$ & $\begin{array}{c}-0.047^{* * *} \\
(0.003)\end{array}$ & $\begin{array}{c}-0.031 * * * \\
(0.002)\end{array}$ \\
\hline 5 years after birth & $\begin{array}{c}-0.060 * * * \\
(0.002)\end{array}$ & $\begin{array}{c}-0.059 * * * \\
(0.002)\end{array}$ & $\begin{array}{c}-0.040 * * * \\
(0.003)\end{array}$ & $\begin{array}{c}-0.047^{* * *} \\
(0.003)\end{array}$ & $\begin{array}{c}-0.040 * * * \\
(0.003)\end{array}$ & $\begin{array}{c}-0.046^{* * *} \\
(0.003)\end{array}$ & $\begin{array}{c}-0.041 * * * \\
(0.003)\end{array}$ & $\begin{array}{c}-0.046 * * * \\
(0.003)\end{array}$ & $\begin{array}{c}-0.030 * * * \\
(0.002)\end{array}$ \\
\hline 6 years after birth & $\begin{array}{c}-0.061^{* * *} \\
(0.002)\end{array}$ & $\begin{array}{c}-0.061 * * * \\
(0.002)\end{array}$ & $\begin{array}{c}-0.041 * * * \\
(0.003)\end{array}$ & $\begin{array}{c}-0.049 * * * \\
(0.003)\end{array}$ & $\begin{array}{c}-0.042^{* * *} \\
(0.003)\end{array}$ & $\begin{array}{c}-0.048^{* * *} \\
(0.003)\end{array}$ & $\begin{array}{c}-0.043 * * * \\
(0.003)\end{array}$ & $\begin{array}{c}-0.047^{* * *} \\
(0.003)\end{array}$ & $\begin{array}{c}-0.028^{* * *} \\
(0.002)\end{array}$ \\
\hline 7 years after birth & $\begin{array}{c}-0.063^{* * *} \\
(0.002)\end{array}$ & $\begin{array}{c}-0.062 * * * \\
(0.002)\end{array}$ & $\begin{array}{c}-0.042^{* * *} \\
(0.003)\end{array}$ & $\begin{array}{c}-0.049 * * * \\
(0.003)\end{array}$ & $\begin{array}{c}-0.043^{* * *} \\
(0.003)\end{array}$ & $\begin{array}{c}-0.048^{* * *} \\
(0.003)\end{array}$ & $\begin{array}{c}-0.043^{* * *} \\
(0.003)\end{array}$ & $\begin{array}{c}-0.047^{* * *} \\
(0.003)\end{array}$ & $\begin{array}{c}-0.030 * * * \\
(0.003)\end{array}$ \\
\hline second child & & $\begin{array}{l}-0.001 \\
(0.001)\end{array}$ & $\begin{array}{c}0.001 \\
(0.002)\end{array}$ & $\begin{array}{l}-0.002 \\
(0.002)\end{array}$ & $\begin{array}{l}-0.001 \\
(0.002)\end{array}$ & $\begin{array}{l}-0.002 \\
(0.002)\end{array}$ & $\begin{array}{l}-0.001 \\
(0.002)\end{array}$ & $\begin{array}{c}-0.005^{* * *} \\
(0.002)\end{array}$ & $\begin{array}{c}-0.003^{* *} \\
(0.002)\end{array}$ \\
\hline second child $*$ mother & & $\begin{array}{l}0.004^{*} \\
(0.002)\end{array}$ & $\begin{array}{c}0.002 \\
(0.003)\end{array}$ & $\begin{array}{c}0.004 \\
(0.003)\end{array}$ & $\begin{array}{c}0.002 \\
(0.003)\end{array}$ & $\begin{array}{c}0.004 \\
(0.003)\end{array}$ & $\begin{array}{c}0.004 \\
(0.003)\end{array}$ & $\begin{array}{c}0.003 \\
(0.003)\end{array}$ & $\begin{array}{l}0.005^{*} \\
(0.003)\end{array}$ \\
\hline elasticity of salary wrt. hours worked & & & $\begin{array}{c}0.538 * * * \\
(0.008)\end{array}$ & & & & $\begin{array}{c}0.433^{* * *} \\
(0.010)\end{array}$ & $\begin{array}{c}0.393^{* * *} \\
(0.010)\end{array}$ & \\
\hline $\begin{array}{l}\text { elasticity of salary wrt. hours worked } * \\
\text { mother }\end{array}$ & & & $0.057^{* * *}$ & & & & $0.410^{* * *}$ & $0.425^{* * *}$ & \\
\hline
\end{tabular}




\begin{tabular}{|c|c|c|c|c|c|c|c|c|c|}
\hline & (1) & $(2)$ & (3) & (4) & (5) & & (7) & (8) & (9) \\
\hline & No controls & $\begin{array}{l}+ \text { Second } \\
\text { child }\end{array}$ & + Convexity & $\begin{array}{l}+ \text { Time } \\
\text { pressure }\end{array}$ & $\begin{array}{c}+ \text { Contact } \\
\text { with others }\end{array}$ & $\begin{array}{c}+ \text { Freedom to } \\
\text { make } \\
\text { decisions }\end{array}$ & All controls & + College & $\begin{array}{c}\text { Occupation } \\
\text { dummies }\end{array}$ \\
\hline & & & $(0.002)$ & & & & $(0.015)$ & $(0.015)$ & \\
\hline \multirow[t]{2}{*}{ time pressure } & & & & $-0.077^{* * *}$ & & & $-0.045 * * *$ & $-0.033 * * *$ & \\
\hline & & & & $(0.001)$ & & & $(0.002)$ & $(0.002)$ & \\
\hline \multirow[t]{2}{*}{ time pressure $*$ mother } & & & & $0.009 * * *$ & & & $-0.071 * * *$ & $-0.080 * * *$ & \\
\hline & & & & $(0.001)$ & & & $(0.003)$ & $(0.003)$ & \\
\hline \multirow[t]{2}{*}{ contact with others } & & & & & $0.065 * * *$ & & $0.039 * * *$ & $0.052 * * *$ & \\
\hline & & & & & $(0.002)$ & & $(0.002)$ & $(0.002)$ & \\
\hline \multirow[t]{2}{*}{ contact with others * mother } & & & & & $0.012^{* * *}$ & & $-0.028 * * *$ & $-0.023 * * *$ & \\
\hline & & & & & $(0.001)$ & & $(0.003)$ & $(0.003)$ & \\
\hline \multirow[t]{2}{*}{ freedom to make decisions } & & & & & & $-0.028 * * *$ & $-0.003 * * *$ & $0.004 * * *$ & \\
\hline & & & & & & $(0.001)$ & $(0.001)$ & $(0.001)$ & \\
\hline \multirow[t]{2}{*}{ freedom to make decisions * mother } & & & & & & $0.020 * * *$ & $0.005^{* * *}$ & $0.005^{* * *}$ & \\
\hline & & & & & & $(0.001)$ & $(0.002)$ & $(0.002)$ & \\
\hline \multirow[t]{2}{*}{ ISCO 11} & & & & & & & & & $0.418^{*}$ \\
\hline & & & & & & & & & $(0.227)$ \\
\hline \multirow[t]{2}{*}{ ISCO 23} & & & & & & & & & $0.606 * * *$ \\
\hline & & & & & & & & & $(0.225)$ \\
\hline \multirow[t]{2}{*}{ ISCO 33} & & & & & & & & & $0.707 * * *$ \\
\hline & & & & & & & & & $(0.225)$ \\
\hline \multirow[t]{2}{*}{ college } & & & & & & & & $0.052 * * *$ & \\
\hline & & & & & & & & $(0.001)$ & \\
\hline \multirow[t]{2}{*}{ constant } & $0.139 * * *$ & $0.139 * * *$ & $-0.432 * * *$ & $0.473 * * *$ & $-0.121^{* * *}$ & $0.228 * * *$ & $-0.284 * * *$ & $-0.375^{* * *}$ & 0.070 \\
\hline & $(0.001)$ & $(0.001)$ & $(0.008)$ & $(0.006)$ & $(0.007)$ & $(0.002)$ & $(0.013)$ & $(0.013)$ & $(0.225)$ \\
\hline Observations & 586,065 & 586,065 & 531,118 & 459,483 & 459,483 & 459,483 & 458,813 & 458,813 & 457,236 \\
\hline R-squared & 0.031 & 0.031 & 0.052 & 0.057 & 0.056 & 0.053 & 0.071 & 0.078 & 0.228 \\
\hline
\end{tabular}

Notes: Table reports coefficients from a set of OLS regressions of the switching indicator (equal to one if a switch from the private to the public sector occurs between time $\mathrm{t}-1$ and $\mathrm{t}$ ) on dummies corresponding to distances to and from birth and other explanatory variables. Each column in this table corresponds to a different set of control variables. In column 9 a full set of occupation dummies is included; we report just those which significantly differ from the rest. The estimation sample consists of all mothers and fathers who had their first child in the age-interval 26-33 and were employed in the private sector in year t-1.

*** Significant at the 1 percent level.

** Significant at the 5 percent level.

* Significant at the 10 percent level. 


\begin{tabular}{|c|c|c|c|c|c|c|c|c|}
\hline VARIABLES & $\begin{array}{c}\text { (1) } \\
\text { No controls }\end{array}$ & $\begin{array}{c}\text { (2) } \\
+ \text { Second child }\end{array}$ & $\begin{array}{c}\text { (3) } \\
+ \text { Convexity }\end{array}$ & $\begin{array}{c}(4) \\
+ \text { Time } \\
\text { pressure }\end{array}$ & $\begin{array}{c}\text { (5) } \\
+ \text { Contact } \\
\text { with others }\end{array}$ & $\begin{array}{c}(6) \\
+ \text { Freedom to } \\
\text { make } \\
\text { decisions } \\
\end{array}$ & $\begin{array}{c}\text { (7) } \\
\text { All controls }\end{array}$ & $\begin{array}{c}\text { (8) } \\
+ \text { College }\end{array}$ \\
\hline Sector tenure & $\begin{array}{c}-0.054^{* * *} \\
(0.000)\end{array}$ & $\begin{array}{c}-0.054^{* * *} \\
(0.000)\end{array}$ & $\begin{array}{c}-0.052^{* * *} \\
(0.000)\end{array}$ & $\begin{array}{c}-0.051^{* * *} \\
(0.000)\end{array}$ & $\begin{array}{c}-0.051^{* * *} \\
(0.000)\end{array}$ & $\begin{array}{c}-0.051^{* * *} \\
(0.000)\end{array}$ & $\begin{array}{c}-0.051^{* * *} \\
(0.000)\end{array}$ & $\begin{array}{c}-0.048^{* * *} \\
(0.000)\end{array}$ \\
\hline 4 years before birth $*$ mother & $\begin{array}{c}-0.058^{* * *} \\
(0.008)\end{array}$ & $\begin{array}{c}-0.058^{* * *} \\
(0.008)\end{array}$ & $\begin{array}{l}-0.018 \\
(0.011)\end{array}$ & $\begin{array}{l}-0.003 \\
(0.012)\end{array}$ & $\begin{array}{c}-0.045^{* * *} \\
(0.012)\end{array}$ & $\begin{array}{c}0.007 \\
(0.010)\end{array}$ & $\begin{array}{l}-0.015 \\
(0.012)\end{array}$ & $\begin{array}{c}-0.025 * * * \\
(0.008)\end{array}$ \\
\hline 3 years before birth $*$ mother & $\begin{array}{c}-0.064^{* * *} \\
(0.007)\end{array}$ & $\begin{array}{c}-0.064 * * * \\
(0.007)\end{array}$ & $\begin{array}{c}-0.028^{* *} \\
(0.011)\end{array}$ & $\begin{array}{l}-0.008 \\
(0.012)\end{array}$ & $\begin{array}{c}-0.050 * * * \\
(0.011)\end{array}$ & $\begin{array}{c}0.003 \\
(0.010)\end{array}$ & $\begin{array}{l}-0.022^{*} \\
(0.012)\end{array}$ & $\begin{array}{c}-0.028 * * * \\
(0.008)\end{array}$ \\
\hline 2 years before birth $*$ mother & $\begin{array}{c}-0.085^{* * *} \\
(0.007)\end{array}$ & $\begin{array}{c}-0.085 * * * \\
(0.007)\end{array}$ & $\begin{array}{c}-0.044 * * * \\
(0.011)\end{array}$ & $\begin{array}{c}-0.026^{* *} \\
(0.011)\end{array}$ & $\begin{array}{c}-0.067^{* * *} \\
(0.011)\end{array}$ & $\begin{array}{l}-0.015 \\
(0.010)\end{array}$ & $\begin{array}{c}-0.037^{* * *} \\
(0.011)\end{array}$ & $\begin{array}{c}-0.043 * * * \\
(0.007)\end{array}$ \\
\hline 1 year before birth $*$ mother & $\begin{array}{c}-0.101^{* * *} \\
(0.007)\end{array}$ & $\begin{array}{c}-0.101 * * * \\
(0.007)\end{array}$ & $\begin{array}{c}-0.061 * * * \\
(0.011)\end{array}$ & $\begin{array}{c}-0.048 * * * \\
(0.011)\end{array}$ & $\begin{array}{c}-0.088^{* * *} \\
(0.011)\end{array}$ & $\begin{array}{c}-0.037 * * * \\
(0.010)\end{array}$ & $\begin{array}{c}-0.060^{* * *} \\
(0.011)\end{array}$ & $\begin{array}{c}-0.047 * * * \\
(0.007)\end{array}$ \\
\hline birth year * mother & $\begin{array}{c}-0.134^{* * *} \\
(0.008)\end{array}$ & $\begin{array}{c}-0.134 * * * \\
(0.008)\end{array}$ & $\begin{array}{c}-0.092 * * * \\
(0.011)\end{array}$ & $\begin{array}{c}-0.070 * * * \\
(0.012)\end{array}$ & $\begin{array}{c}-0.113^{* * *} \\
(0.012)\end{array}$ & $\begin{array}{c}-0.060 * * * \\
(0.010)\end{array}$ & $\begin{array}{c}-0.083^{* * *} \\
(0.012)\end{array}$ & $\begin{array}{c}-0.078 * * * \\
(0.008)\end{array}$ \\
\hline 1 year after birth $*$ mother & $\begin{array}{c}-0.134^{* * *} \\
(0.008)\end{array}$ & $\begin{array}{c}-0.134 * * * \\
(0.007)\end{array}$ & $\begin{array}{c}-0.090 * * * \\
(0.011)\end{array}$ & $\begin{array}{c}-0.074 * * * \\
(0.012)\end{array}$ & $\begin{array}{c}-0.115^{* * *} \\
(0.012)\end{array}$ & $\begin{array}{c}-0.062 * * * \\
(0.010)\end{array}$ & $\begin{array}{c}-0.085^{* * *} \\
(0.012)\end{array}$ & $\begin{array}{c}-0.067 * * * \\
(0.008)\end{array}$ \\
\hline 2 years after birth $*$ mother & $\begin{array}{c}-0.147^{* * *} \\
(0.007)\end{array}$ & $\begin{array}{c}-0.147^{* * *} \\
(0.007)\end{array}$ & $\begin{array}{c}-0.106^{* * *} \\
(0.011)\end{array}$ & $\begin{array}{c}-0.090 * * * \\
(0.011)\end{array}$ & $\begin{array}{c}-0.131^{* * *} \\
(0.011)\end{array}$ & $\begin{array}{c}-0.077^{* * *} \\
(0.010)\end{array}$ & $\begin{array}{c}-0.103^{* * *} \\
(0.011)\end{array}$ & $\begin{array}{c}-0.075^{* * *} \\
(0.007)\end{array}$ \\
\hline 3 years after birth $*$ mother & $\begin{array}{c}-0.150^{* * *} \\
(0.007)\end{array}$ & $\begin{array}{c}-0.148^{* * *} \\
(0.008)\end{array}$ & $\begin{array}{c}-0.106 * * * \\
(0.011)\end{array}$ & $\begin{array}{c}-0.083 * * * \\
(0.012)\end{array}$ & $\begin{array}{c}-0.126^{* * *} \\
(0.012)\end{array}$ & $\begin{array}{c}-0.072 * * * \\
(0.010)\end{array}$ & $\begin{array}{c}-0.096 * * * \\
(0.012)\end{array}$ & $\begin{array}{c}-0.073 * * * \\
(0.008)\end{array}$ \\
\hline 4 years after birth $*$ mother & $\begin{array}{c}-0.134^{* * *} \\
(0.007)\end{array}$ & $\begin{array}{c}-0.130 * * * \\
(0.008)\end{array}$ & $\begin{array}{c}-0.094 * * * \\
(0.012)\end{array}$ & $\begin{array}{c}-0.065^{* * *} \\
(0.012)\end{array}$ & $\begin{array}{c}-0.110 * * * \\
(0.012)\end{array}$ & $\begin{array}{c}-0.054 * * * \\
(0.011)\end{array}$ & $\begin{array}{c}-0.079 * * * \\
(0.012)\end{array}$ & $\begin{array}{c}-0.045^{* * *} \\
(0.009)\end{array}$ \\
\hline 5 years after birth $*$ mother & $\begin{array}{c}-0.147^{* * *} \\
(0.007)\end{array}$ & $\begin{array}{c}-0.142 * * * \\
(0.009)\end{array}$ & $\begin{array}{c}-0.098 * * * \\
(0.012)\end{array}$ & $\begin{array}{c}-0.068 * * * \\
(0.013)\end{array}$ & $\begin{array}{c}-0.114^{* * *} \\
(0.013)\end{array}$ & $\begin{array}{c}-0.057 * * * \\
(0.012)\end{array}$ & $\begin{array}{c}-0.081^{* * *} \\
(0.013)\end{array}$ & $\begin{array}{c}-0.045^{* * *} \\
(0.009)\end{array}$ \\
\hline 6 years after birth $*$ mother & $\begin{array}{c}-0.142^{* * *} \\
(0.008)\end{array}$ & $\begin{array}{c}-0.137^{* * *} \\
(0.010)\end{array}$ & $\begin{array}{c}-0.093 * * * \\
(0.013)\end{array}$ & $\begin{array}{c}-0.065^{* * *} \\
(0.013)\end{array}$ & $\begin{array}{c}-0.110 * * * \\
(0.013)\end{array}$ & $\begin{array}{c}-0.053^{* * *} \\
(0.012)\end{array}$ & $\begin{array}{c}-0.076^{* * *} \\
(0.013)\end{array}$ & $\begin{array}{c}-0.045^{* * *} \\
(0.010)\end{array}$ \\
\hline 7 years after birth $*$ mother & $\begin{array}{c}-0.118^{* * *} \\
(0.008)\end{array}$ & $\begin{array}{c}-0.112^{* * *} \\
(0.010)\end{array}$ & $\begin{array}{c}-0.068^{* * *} \\
(0.013)\end{array}$ & $\begin{array}{c}-0.043^{* * *} \\
(0.014)\end{array}$ & $\begin{array}{c}-0.089 * * * \\
(0.014)\end{array}$ & $\begin{array}{c}-0.033^{* *} \\
(0.013)\end{array}$ & $\begin{array}{c}-0.056^{* * *} \\
(0.014)\end{array}$ & $\begin{array}{l}-0.018^{*} \\
(0.010)\end{array}$ \\
\hline 4 years before birth & $\begin{array}{c}0.007 \\
(0.007)\end{array}$ & $\begin{array}{c}0.007 \\
(0.007)\end{array}$ & $\begin{array}{c}-0.020^{* *} \\
(0.009)\end{array}$ & $\begin{array}{c}-0.030 * * * \\
(0.009)\end{array}$ & $\begin{array}{l}-0.005 \\
(0.009)\end{array}$ & $\begin{array}{c}-0.036^{* * *} \\
(0.008)\end{array}$ & $\begin{array}{c}-0.023 * * \\
(0.009)\end{array}$ & $\begin{array}{c}0.008 \\
(0.008)\end{array}$ \\
\hline
\end{tabular}




\begin{tabular}{|c|c|c|c|c|c|c|c|c|}
\hline VARIABLES & $\begin{array}{c}\text { (1) } \\
\text { No controls }\end{array}$ & $\begin{array}{c}\text { (2) } \\
+ \text { Second child }\end{array}$ & $\begin{array}{c}\text { (3) } \\
+ \text { Convexity }\end{array}$ & $\begin{array}{c}\text { (4) } \\
+ \text { Time } \\
\text { pressure }\end{array}$ & $\begin{array}{c}\text { (5) } \\
+ \text { Contact } \\
\text { with others }\end{array}$ & $\begin{array}{c}(6) \\
+ \text { Freedom to } \\
\text { make } \\
\text { decisions }\end{array}$ & $\begin{array}{c}\text { (7) } \\
\text { All controls }\end{array}$ & $\begin{array}{c}(8) \\
+ \text { College }\end{array}$ \\
\hline 3 years before birth & $\begin{array}{l}-0.008 \\
(0.007)\end{array}$ & $\begin{array}{l}-0.008 \\
(0.007)\end{array}$ & $\begin{array}{c}-0.033^{* * *} \\
(0.009)\end{array}$ & $\begin{array}{c}-0.045^{* * *} \\
(0.009)\end{array}$ & $\begin{array}{c}-0.021 * * \\
(0.009)\end{array}$ & $\begin{array}{c}-0.053^{* * *} \\
(0.008)\end{array}$ & $\begin{array}{c}-0.037 * * * \\
(0.009)\end{array}$ & $\begin{array}{c}0.003 \\
(0.007)\end{array}$ \\
\hline 2 years before birth & $\begin{array}{l}-0.006 \\
(0.007)\end{array}$ & $\begin{array}{l}-0.006 \\
(0.007)\end{array}$ & $\begin{array}{c}-0.034^{* * *} \\
(0.009)\end{array}$ & $\begin{array}{c}-0.046 * * * \\
(0.009)\end{array}$ & $\begin{array}{c}-0.023 * * \\
(0.009)\end{array}$ & $\begin{array}{c}-0.055^{* * *} \\
(0.008)\end{array}$ & $\begin{array}{c}-0.040^{* * *} \\
(0.009)\end{array}$ & $\begin{array}{c}0.011 \\
(0.007)\end{array}$ \\
\hline 1 year before birth & $\begin{array}{l}-0.007 \\
(0.007)\end{array}$ & $\begin{array}{l}-0.007 \\
(0.007)\end{array}$ & $\begin{array}{c}-0.036 * * * \\
(0.009)\end{array}$ & $\begin{array}{c}-0.047^{* * *} \\
(0.009)\end{array}$ & $\begin{array}{c}-0.023 * * \\
(0.009)\end{array}$ & $\begin{array}{c}-0.055^{* * *} \\
(0.008)\end{array}$ & $\begin{array}{c}-0.039 * * * \\
(0.009)\end{array}$ & $\begin{array}{c}0.005 \\
(0.007)\end{array}$ \\
\hline birth year & $\begin{array}{l}-0.011 \\
(0.007)\end{array}$ & $\begin{array}{l}-0.011 \\
(0.007)\end{array}$ & $\begin{array}{c}-0.037^{* * *} \\
(0.009)\end{array}$ & $\begin{array}{c}-0.054 * * * \\
(0.009)\end{array}$ & $\begin{array}{c}-0.029 * * * \\
(0.009)\end{array}$ & $\begin{array}{c}-0.061 * * * \\
(0.008)\end{array}$ & $\begin{array}{c}-0.047^{* * *} \\
(0.009)\end{array}$ & $\begin{array}{c}0.000 \\
(0.007)\end{array}$ \\
\hline 1 year after birth & $\begin{array}{c}-0.025^{* * *} \\
(0.007)\end{array}$ & $\begin{array}{c}-0.025^{* * *} \\
(0.007)\end{array}$ & $\begin{array}{c}-0.054^{* * *} \\
(0.009)\end{array}$ & $\begin{array}{c}-0.066^{* * *} \\
(0.009)\end{array}$ & $\begin{array}{c}-0.041^{* * *} \\
(0.009)\end{array}$ & $\begin{array}{c}-0.074 * * * \\
(0.008)\end{array}$ & $\begin{array}{c}-0.059 * * * \\
(0.009)\end{array}$ & $\begin{array}{c}-0.018^{* *} \\
(0.007)\end{array}$ \\
\hline 2 years after birth & $\begin{array}{c}-0.024^{* * *} \\
(0.007)\end{array}$ & $\begin{array}{c}-0.023^{* * *} \\
(0.007)\end{array}$ & $\begin{array}{c}-0.051^{* * *} \\
(0.009)\end{array}$ & $\begin{array}{c}-0.062^{* * *} \\
(0.009)\end{array}$ & $\begin{array}{c}-0.039 * * * \\
(0.009)\end{array}$ & $\begin{array}{c}-0.071^{* * *} \\
(0.008)\end{array}$ & $\begin{array}{c}-0.053^{* * *} \\
(0.009)\end{array}$ & $\begin{array}{c}-0.025 * * * \\
(0.007)\end{array}$ \\
\hline 3 years after birth & $\begin{array}{c}-0.020^{* * *} \\
(0.007)\end{array}$ & $\begin{array}{c}-0.014 * * \\
(0.007)\end{array}$ & $\begin{array}{c}-0.043^{* * *} \\
(0.009)\end{array}$ & $\begin{array}{c}-0.065^{* * *} \\
(0.009)\end{array}$ & $\begin{array}{c}-0.040^{* * *} \\
(0.009)\end{array}$ & $\begin{array}{c}-0.073^{* * *} \\
(0.008)\end{array}$ & $\begin{array}{c}-0.057^{* * *} \\
(0.009)\end{array}$ & $\begin{array}{c}-0.026 * * * \\
(0.007)\end{array}$ \\
\hline 4 years after birth & $\begin{array}{c}-0.030 * * * \\
(0.007)\end{array}$ & $\begin{array}{c}-0.018^{* *} \\
(0.007)\end{array}$ & $\begin{array}{c}-0.043 * * * \\
(0.009)\end{array}$ & $\begin{array}{c}-0.067 * * * \\
(0.010)\end{array}$ & $\begin{array}{c}-0.041^{* * *} \\
(0.010)\end{array}$ & $\begin{array}{c}-0.075^{* * *} \\
(0.009)\end{array}$ & $\begin{array}{c}-0.058^{* * *} \\
(0.010)\end{array}$ & $\begin{array}{c}-0.042 * * * \\
(0.008)\end{array}$ \\
\hline 5 years after birth & $\begin{array}{c}-0.029 * * * \\
(0.007)\end{array}$ & $\begin{array}{l}-0.015^{*} \\
(0.008)\end{array}$ & $\begin{array}{c}-0.046^{* * *} \\
(0.010)\end{array}$ & $\begin{array}{c}-0.075^{* * *} \\
(0.010)\end{array}$ & $\begin{array}{c}-0.047^{* * *} \\
(0.010)\end{array}$ & $\begin{array}{c}-0.083^{* * *} \\
(0.009)\end{array}$ & $\begin{array}{c}-0.067^{* * *} \\
(0.010)\end{array}$ & $\begin{array}{c}-0.053 * * * \\
(0.008)\end{array}$ \\
\hline 6 years after birth & $\begin{array}{c}-0.029 * * * \\
(0.007)\end{array}$ & $\begin{array}{l}-0.014^{*} \\
(0.008)\end{array}$ & $\begin{array}{c}-0.045^{* * *} \\
(0.010)\end{array}$ & $\begin{array}{c}-0.068^{* * *} \\
(0.010)\end{array}$ & $\begin{array}{c}-0.041^{* * *} \\
(0.010)\end{array}$ & $\begin{array}{c}-0.077^{* * *} \\
(0.010)\end{array}$ & $\begin{array}{c}-0.063^{* * *} \\
(0.010)\end{array}$ & $\begin{array}{c}-0.048 * * * \\
(0.009)\end{array}$ \\
\hline 7 years after birth & $\begin{array}{c}-0.042^{* * *} \\
(0.008)\end{array}$ & $\begin{array}{c}-0.026^{* * *} \\
(0.009)\end{array}$ & $\begin{array}{c}-0.060 * * * \\
(0.010)\end{array}$ & $\begin{array}{c}-0.078 * * * \\
(0.011)\end{array}$ & $\begin{array}{c}-0.051^{* * *} \\
(0.011)\end{array}$ & $\begin{array}{c}-0.088^{* * *} \\
(0.010)\end{array}$ & $\begin{array}{c}-0.072^{* * *} \\
(0.011)\end{array}$ & $\begin{array}{c}-0.065 * * * \\
(0.009)\end{array}$ \\
\hline second child & & $\begin{array}{c}-0.020 * * * \\
(0.006)\end{array}$ & $\begin{array}{c}-0.026 * * * \\
(0.006)\end{array}$ & $\begin{array}{c}-0.016 * * * \\
(0.006)\end{array}$ & $\begin{array}{c}-0.019 * * * \\
(0.006)\end{array}$ & $\begin{array}{c}-0.016^{* *} \\
(0.006)\end{array}$ & $\begin{array}{c}-0.017^{* * *} \\
(0.006)\end{array}$ & $\begin{array}{l}-0.006 \\
(0.006)\end{array}$ \\
\hline second child * mother & & $\begin{array}{l}-0.006 \\
(0.007)\end{array}$ & $\begin{array}{c}0.002 \\
(0.008)\end{array}$ & $\begin{array}{l}-0.006 \\
(0.008)\end{array}$ & $\begin{array}{c}0.000 \\
(0.008)\end{array}$ & $\begin{array}{l}-0.004 \\
(0.008)\end{array}$ & $\begin{array}{c}-0.003 \\
(0.008)\end{array}$ & $\begin{array}{l}-0.010 \\
(0.007)\end{array}$ \\
\hline elasticity of salary wrt. hours worked & & & $\begin{array}{c}-0.770 * * * \\
(0.025)\end{array}$ & & & & $\begin{array}{c}-0.720 * * * \\
(0.034)\end{array}$ & \\
\hline elasticity of salary wrt. hours worked $*$ mother & & & $\begin{array}{c}-0.037^{* * *} \\
(0.007)\end{array}$ & & & & $\begin{array}{c}-0.092 * * \\
(0.042)\end{array}$ & \\
\hline time pressure & & & & $\begin{array}{c}0.206 * * * \\
(0.005)\end{array}$ & & & $\begin{array}{c}0.159 * * * \\
(0.007)\end{array}$ & \\
\hline
\end{tabular}




\begin{tabular}{|c|c|c|c|c|c|c|c|c|}
\hline & (1) & (2) & (3) & (4) & (5) & (6) & (7) & (8) \\
\hline VARIABLES & No controls & + Second child & + Convexity & $\begin{array}{l}+ \text { Time } \\
\text { pressure }\end{array}$ & $\begin{array}{c}+ \text { Contact } \\
\text { with others }\end{array}$ & $\begin{array}{c}+ \text { Freedom to } \\
\text { make } \\
\text { decisions }\end{array}$ & All controls & + College \\
\hline time pressure $*$ mother & & & & $\begin{array}{c}-0.016 * * * \\
(0.002)\end{array}$ & & & $\begin{array}{c}-0.079 * * * \\
(0.009)\end{array}$ & \\
\hline contact with others & & & & & $\begin{array}{c}-0.164^{* * *} \\
(0.004)\end{array}$ & & $\begin{array}{c}-0.144 * * * \\
(0.006)\end{array}$ & \\
\hline contact with others $*$ mother & & & & & $\begin{array}{l}-0.003 \\
(0.002)\end{array}$ & & $\begin{array}{c}0.077^{* * *} \\
(0.007)\end{array}$ & \\
\hline freedom to make decisions & & & & & & $\begin{array}{c}0.081^{* * *} \\
(0.003)\end{array}$ & $\begin{array}{c}0.016^{* * *} \\
(0.004)\end{array}$ & \\
\hline freedom to make decisions $*$ mother & & & & & & $\begin{array}{c}-0.039 * * * \\
(0.003)\end{array}$ & $\begin{array}{c}0.016^{* * *} \\
(0.005)\end{array}$ & \\
\hline college & & & & & & & $\begin{array}{c}-0.073^{* * *} \\
(0.002)\end{array}$ & \\
\hline constant & $\begin{array}{c}0.779 * * * \\
(0.004)\end{array}$ & $\begin{array}{c}0.779 * * * \\
(0.004)\end{array}$ & $\begin{array}{c}1.619 * * * \\
(0.026)\end{array}$ & $\begin{array}{c}0.001 \\
(0.019)\end{array}$ & $\begin{array}{c}1.497^{* * *} \\
(0.018)\end{array}$ & $\begin{array}{c}0.646 * * * \\
(0.006)\end{array}$ & $\begin{array}{c}1.550 * * * \\
(0.043)\end{array}$ & $\begin{array}{c}-1.127 \\
(2,610.479)\end{array}$ \\
\hline Observations & 195,830 & 195,830 & 183,107 & 165,172 & 165,172 & 165,172 & 165,031 & 161,473 \\
\hline R-squared & 0.177 & 0.177 & 0.169 & 0.174 & 0.174 & 0.170 & 0.183 & 0.307 \\
\hline
\end{tabular}

Notes: Table reports coefficients from a set of OLS regressions of the switching indicator (equal to one if a switch from the public to the private sector occurs between time t-1 and t) on dummies corresponding to distances to and from birth and other explanatory variables. Each column in this table corresponds to a different set of control variables. The estimation sample consists of all mothers and fathers who had their first child in the ageinterval 26-33 and were employed in the public sector in year t-1.

*** Significant at the 1 percent level.

** Significant at the 5 percent level.

* Significant at the 10 percent level. 


\begin{tabular}{|c|c|c|}
\hline ISCO code & Occupation title & Elasticity \\
\hline 12 & Administrative and commercial managers & $\begin{array}{l}1.038 \\
(0.007)\end{array}$ \\
\hline 13 & Production and specialised services managers & $\begin{array}{l}1.114 \\
(0.008)\end{array}$ \\
\hline 21 & Science and engineering professionals & $\begin{array}{l}1.016 \\
(0.003)\end{array}$ \\
\hline 22 & Health professionals & $\begin{array}{l}1.092 \\
(0.008)\end{array}$ \\
\hline 23 & Teaching professionals & $\begin{array}{l}1.075 \\
(0.003)\end{array}$ \\
\hline 24 & Business and administration professionals & $\begin{array}{l}1.115 \\
(0.004)\end{array}$ \\
\hline 31 & Science and engineering associate professionals & $\begin{array}{l}1.111 \\
(0.003)\end{array}$ \\
\hline 32 & Health associate professionals & $\begin{array}{l}1.092 \\
(0.008)\end{array}$ \\
\hline 33 & Business and administration associate professionals & $\begin{array}{l}1.087 \\
(0.005)\end{array}$ \\
\hline 34 & Legal, social, cultural and related associate professionals & $\begin{array}{l}1.058 \\
(0.003)\end{array}$ \\
\hline 41 & General and keyboard clerks & $\begin{array}{l}1.034 \\
(0.002)\end{array}$ \\
\hline 42 & Customer services clerks & $\begin{array}{l}1.084 \\
(0.006)\end{array}$ \\
\hline 51 & Personal service workers & $\begin{array}{l}1.136 \\
(0.003)\end{array}$ \\
\hline 52 & Sales workers & $\begin{array}{l}1.046 \\
(0.003)\end{array}$ \\
\hline 61 & Market-oriented skilled agricultural workers & $\begin{array}{l}0.976 \\
(0.006)\end{array}$ \\
\hline 71 & Building and related trades workers, excluding electricians & $\begin{array}{l}0.996 \\
(0.002)\end{array}$ \\
\hline 72 & Metal, machinery and related trades workers & $\begin{array}{l}1.015 \\
(0.002)\end{array}$ \\
\hline 73 & Handicraft and printing workers & $\begin{array}{l}0.986 \\
(0.009)\end{array}$ \\
\hline 74 & Electrical and electronic trades workers & $\begin{array}{l}1.018 \\
(0.005)\end{array}$ \\
\hline 81 & Stationary plant and machine operators & $\begin{array}{l}1.115 \\
(0.007)\end{array}$ \\
\hline 82 & Assemblers & $\begin{array}{l}1.109 \\
(0.002)\end{array}$ \\
\hline 83 & Drivers and mobile plant operators & $\begin{array}{l}1.114 \\
(0.003)\end{array}$ \\
\hline 91 & Cleaners and helpers & $\begin{array}{l}1.146 \\
(0.004)\end{array}$ \\
\hline 92 & Agricultural, forestry and fishery labourers & $\begin{array}{l}0.997 \\
(0.007)\end{array}$ \\
\hline
\end{tabular}

Notes: Table lists the coefficients (and standard errors) from the OLS regressions of (log) monthly salary on (log) hours worked for each 2-digit occupation. We control for age and education level in these regressions. Estimation sample consists of men aged 21-37.

*** Significant at the 1 percent level. 
A3. Figures - alternative estimations of the family gap in sector switching (mothers vs. childless women)

Panel A: From private to public

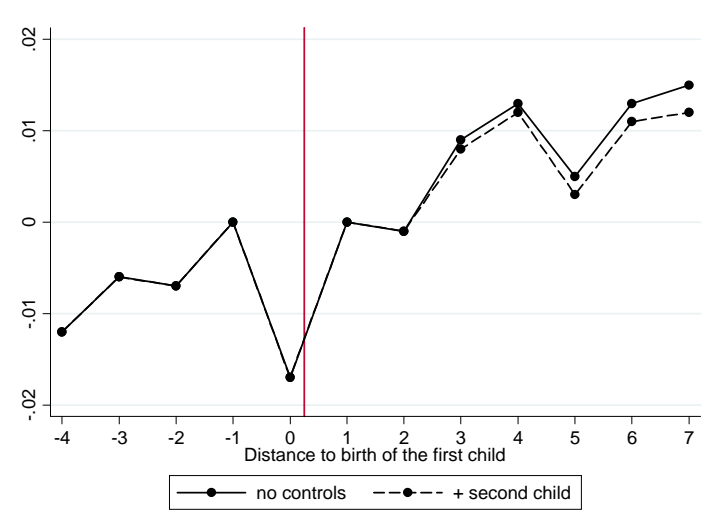

Panel B: From public to private

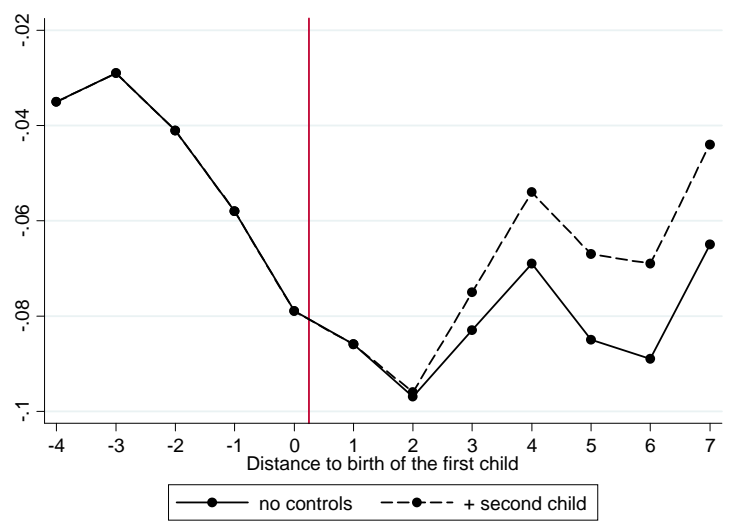

FIGURE 1A. FAMILY GAP IN THE PROBABILITY OF SWITCHING

Note: Each dot represents a point estimate of the coefficient corresponding to the motherhood effect (mothers vs. childless women) at each distance to birth. 